\title{
Multi-Compartmental Modeling for Extracellular Stimulation of Neocortex
}

\author{
Mahmut Emin Çelik \\ Gazi University, Faculty of Engineering, Department of Electrical Electronics Engineering, Ankara, Turkey (ORCID: 0000-0002-1766-5514)
}

(International Symposium on Multidisciplinary Studies and Innovative Technologies (ISMSIT) 2021 - 21-23 October 2021)

(DOI: 10.31590/ejosat.1013879)

ATIF/REFERENCE: Celik, M.E. (2021). Multi-Compartmental Modeling for Extracellular Stimulation of Neocortex. European Journal of Science and Technology, (29), 76-80.

\begin{abstract}
Aim: To explore the natural origin and changing behavior of neural responses depending on varying conditions, computational modeling of single-neuron or cluster of neurons using multi-compartmental models can provide very consistent predictions integrating with experimental work. Neural electrodes are fundamental therapeutic and diagnostic tools for a large variety of conditions. Understanding, individually or together neuronal responses, is critical for therapeutic and diagnostic techniques while dealing with certain neuropathies like Epilepsy or Parkinson's. The electrodes with different sizes and materials are the only way to interface the nervous system when it is needed to restore sensory or motor functions somehow.

Material Method: Multi-compartmental neuron model is prepared by using a neuron with 3D realistic morphology from the neocortex. It is analyzed to see neurons' response to extracellular stimulation using a point source situated in two different locations, one at a time. Ideal conditions are considered for the point source. NEURON v8.0 is used for simulations. The stimulation pulse width, frequency, and amplitude are $1 \mathrm{~ms}, 20 \mathrm{~Hz}$, and $250 \mathrm{nA}$ respectively.

Results: It is seen that the extracellular voltage profile is as expected, then it shifts towards where the stimulation electrode is moved. Closer neural compartments are better targets to generate action potential first. The effect of extracellular stimulation decreases as it moves from the source, but other compartments that are relatively in distance can also generate an action potential in several milliseconds after stimulation onset.

Conclusion: Findings confirm multi-compartmental models are well-suited to predict neuronal responses. Different numbers and types of neurons' responses can be examined together with a complex realistic morphology. Parameters related to experimental conditions, like stimulation and recording, can also be analyzed.
\end{abstract}

Keywords: computational modeling, neuron model, Hodgkin Huxley, neuroscience, stimulation, electrode

\section{Neokorteksin Hücre Dışı Uyarılmasına Yönelik Çok Bölmeli Modelleme}

$\ddot{O} \mathbf{z}$

Amaç: Değişen koşullara bağlı olarak nöral yanıtların doğal kökenini ve değişen davranışını araştırmak için, çok bölmeli modeller kullanarak tek nöron veya nöron kümesinin hesaplamalı modellemesi, deneysel çalışma ile bütünleşen çok tutarlı tahminler sağlayabilir. Nöral elektrotlar, çok çeşitli koşullar için temel terapötik ve teşhis araçlarıdır. Epilepsi veya Parkinson gibi belirli nöropatilerle uğraşırken, tek tek veya birlikte nöronal tepkileri anlamak, terapötik ve tanısal teknikler için kritik öneme sahiptir. Farklı boyut ve malzemelere sahip elektrotlar, duyusal veya motor işlevlerin bir şekilde yeniden sağlanması gerektiğinde sinir sistemiyle arayüz oluşturmanın tek yoludur.

Gereç Yöntemi: Neokorteksten alınan 3B gerçekçi morfolojiye sahip bir nöron kullanılarak çok bölmeli nöron modeli hazırlanır. Her seferinde bir tane olmak üzere iki farklı yerde bulunan bir nokta kaynağı kullanılarak nöronların hücre dışı uyarıma tepkisini görmek için analiz edilir. Nokta kaynak için ideal koşullar göz önünde bulundurulur. NEURON v8.0 simülasyonlar için kullanılır. Stimülasyon darbe genişliği, frekansı ve genliği sırasılyla $1 \mathrm{~ms}, 20 \mathrm{~Hz}$ ve 250 nA'dır.

Bulgular: Hücre dışı voltaj profilinin beklendiği gibi olduğu, ardından stimülasyon elektrotunun hareket ettiği yere doğru kaydığı görüldü. Daha yakın nöral bölmeler, önce aksiyon potansiyeli oluşturmak için daha iyi hedeflerdir. Kaynaktan hareket ettikçe hücre dışı stimülasyonun etkisi azalır, ancak nispeten uzakta olan diğer kompartmanlar da stimülasyonun başlamasından birkaç milisaniye sonra bir aksiyon potansiyeli oluşturabilir.

Sonuç: Bulgular, çok bölmeli modellerin nöronal tepkileri tahmin etmek için çok uygun olduğunu doğrulamaktadır. Farklı sayı ve tipteki nöronların tepkileri, karmaşık bir gerçekçi morfoloji ile birlikte incelenebilir. Stimülasyon ve kayıt gibi deneysel koşullarla ilgili parametreler de analiz edilebilir.

Anahtar Kelimeler: işlemsel modelleme, nöron modeli, Hodgkin Huxley, sinirbilim, uyartım, elektrot. 


\section{Introduction}

Neurological disorders have many adverse effects for patients' social life. Micro electrodes are widely used for both therapeutic approaches and diagnostic techniques. Either relatively large electrodes, around $10 \mathrm{~mm} 2$ to $0.3 \mathrm{~mm} 2$ surface area, for monitoring of Epilepsy and local field potential resulted from deep brain stimulation for the motor symptoms of Parkinson's disease or microelectrodes for single neuron activity are clinically used to probe large number of neurons activity within the brain [1-3]. They are also critical elements for brainmachine interfaces to monitor sensory, motor and cognitive functionality with high resolution in cellular scale [4-9].

Experimental studies suffer from getting useful information when electrodes aren't situated near the targeted cells. It is reported that electrode arrays with low number of channels are not qualified for clinical use because of tissue damage, body reaction and inability to reach neurons within $100 \mu \mathrm{m}$ distance [7-11]. In clinical treatments, advancing from macro-scoping scale, in $\mathrm{mm}$, to micro scale in order to obtain advanced approaches by precisely, even selectively, reaching small neuron populations is the current challenge. Moreover, it is not clear how electrodes with various shapes and dimensions perform to monitor unit or ensemble activity, which limits understanding of cellular level mechanisms and capabilities of developed systems [12-14].

To increase the efficiency of experimental work and to investigate natural origin of the neural signals, computational modeling approaches offer powerful advantages in terms of predicting neural activity accurately. It has a potential for technological improvements by optimizing either electrode design parameters or experimental settings.

Moffitt and McIntyre mimicked single unit activity from brain surface using multi compartmental model and resulted that model neuron was consistent with experimental recording, also predicted well signal amplitude for encapsulation and coating [6]. Other studies showed that electrodes with certain shapes might be more selective [15]. Together with volume conductor models, it was reported that central nervous system stimulation triggers axons of local cells at similar thresholds when conventional stimuli were used, which also affect pre and post-synaptic elements [16]. Another study showed that model predictions were confirmed by experimental work for asymmetric waveforms [17].

In this work, a neuron from neocortex region in the brain with realistic morphology is used to determine how it reacts to extracellular stimulation from different locations, $50 \mu \mathrm{m}$ away from the bottom and top of the neuron. Multi-compartmental neuron model is prepared using NEURON. An ideal point source is used as stimulation electrode with step currents. Extracellular voltages of the compartments in y direction of the neuron are consistent with stimulation electrode locations.

\section{Material and Method}

\subsection{Computational Modeling}

Neurons are formed by many number and types of ions and molecules with positive or negative charges. Mostly, intracellular space is negatively charged while in the end opposite ions moves to both sides of cell membrane. Cell membrane behaves like a capacitor with its insulating feature because of being impermeable to most molecules. Besides, many ion-conducting channels are also embedded, its density and type determines membrane conductance. A cell may include more than ten types of channels that are very selective to ions passing through. In equilibrium, ion flow flowing both directions are equal. Depending on opening or closing of ion channels membrane voltage changes between -90 $\mathrm{mV}$ to $+50 \mathrm{mV}$. Single compartment models define the membrane potential of a cell by only one variable $\mathrm{V}$, while multicompartment models are also able to specify spatial deviation along the cell. Governing equations for both models characterizes how voltage changes as charge flows. Equation below is a basic equation for a single-compartment models.

$$
C_{m} \frac{d V}{d t}=-i_{m}+\frac{i_{e}}{A}
$$

where $C_{m}, V, i_{m}, i_{e}$ and $A$ represents total membrane capacitance, membrane voltage, membrane current, electrode current and membrane surface area. In mathematical modeling of a neuron, left side of the equation uses membrane capacitance to find out how much current is needed to change the membrane voltage while right side equals to total current passing into the cell. A typical equivalent circuit for single compartment model is shown in Fig 1.

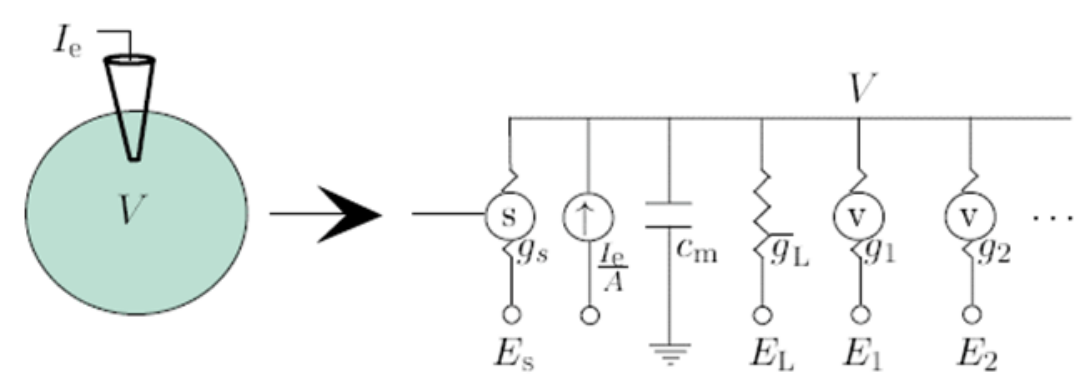

Figure 1. Equivalent circuit for generic representation of single compartment model [21]

It basically consists a capacitor, a number of resistors for each membrane conductance when $\mathrm{v}$ and $\mathrm{g}$ indicate voltage dependent conductance and specific conductance. The more voltagedependent conductance in the model means a larger scope of dynamic behaviors.

Conductance based models are initiated with Hodgkin and Huxley's work to define $\mathrm{Na}+$ and $\mathrm{K}+$ conductance for action potential generation [18]. Conductance based models is an important set of mathematical facts that helps to understand how neural response originates from membrane properties and conductance, then different neuron's behavior when they are embedded into same network. With the cable theory as an analytic approach, multi-compartment models can perform numerical analysis of real complex structures. Each neuron is divided into 
separate sections, i.e. compartments, and membrane voltage is approximated continuously along other compartments. The number of compartments and the length of the neuron mainly determine how accurate a multi-compartment model can define and mimic a real neuron. Fig 2 shows an approximation of a neuron via a multi-compartment model formed by different numbers of discrete pieces.

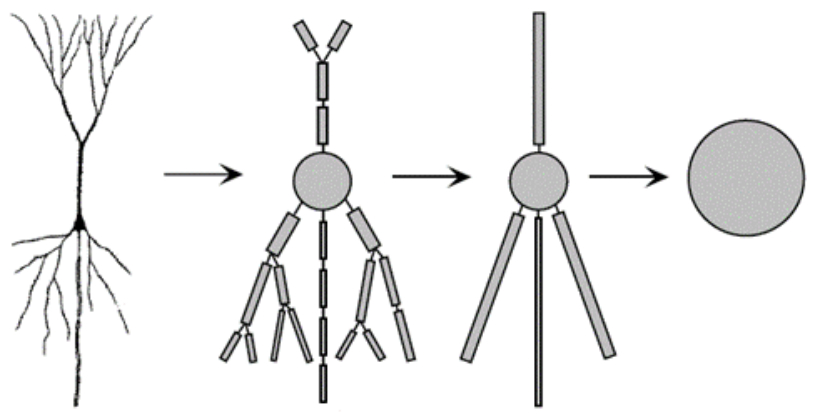

Figure 2. Multi-compartment model approximations with varying number of sections [19]

Each compartment has its own single definitions for membrane voltage, gating variables and membrane current with an equivalent electrical circuit. Each compartment is coupled by a resistor.

\subsection{Model Framework}

There are 3 main compartments, soma, dendrite and axon in multi-compartmental model. The total number of sections and the length of the neuron model are 190 and $9471 \mu \mathrm{m}$ respectively. A neuron from neocortex region of the brain with realistic morphology is used. Biophysical properties, i.e. membrane properties, like resting potential, axial resistivity, membrane capacitance, membrane resistivity, $\mathrm{Na}+$ conductance density and $\mathrm{K}+$ conductance density are inserted to corresponding compartments in line with Mainen's work [20]. NEURON v8.0 is used for simulations.

To see how voltage changes when the neuron is extracellularly stimulated for two different cases, a point source is placed to bottom and top side of the neuron with $50 \mu \mathrm{m}$ distance to nearest compartment. Fig. 3 shows the neuron from neocortex and two electrode locations with red dots. Pulse width, pulse frequency and simulation duration are $1 \mathrm{~ms}, 20 \mathrm{~Hz}$ and 25 ms respectively.

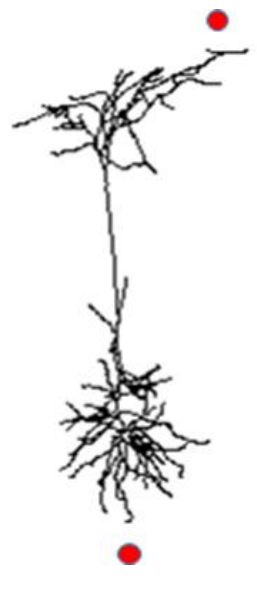

Figure 3. The neuron with realistic morphology and two locations where electrodes are situated, both $50 \mu \mathrm{m}$ away from the nearest compartment

\section{Results and Discussion}

The neuron is stimulated by two different electrodes one at a time, then corresponding extracellular voltage deviation along the $y$-direction of the neuron and membrane voltage of soma, axon and dendrite are analyzed. Electrodes that are situated $50 \mu \mathrm{m}$ away from the nearest compartment in the top and bottom of the neuron spatially correspond to beginning and end of the compartments in y direction. Fig. 4 shows extracellular voltage depending on two different electrode locations.

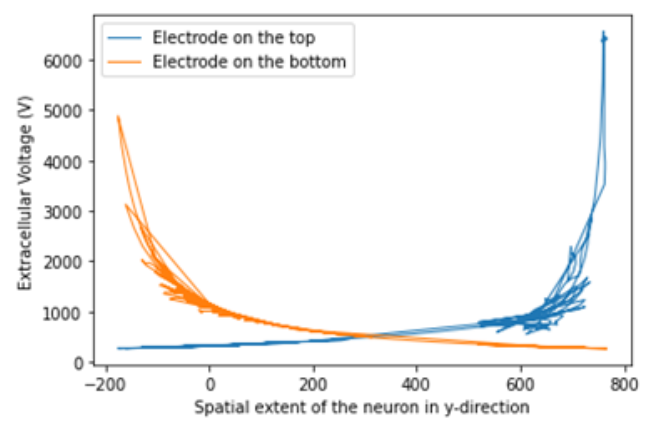

Figure 4. Extracellular voltage difference with respect to two electrode locations

The trend seen extracellular voltage is consistent with the expected voltage gradient considering where electrodes are. When the electrode is near the neural compartments in the bottom part, extracellular voltage is significantly higher around there. Then, it is moved to another position, similarly, extracellular voltage profile is shifted towards other compartments in the opposite site of the neuron model. In our analysis, membrane voltage is also analyzed for two cases. Fig. 5 demonstrates how membrane voltages are affected by extracellular stimulations from two different points. 

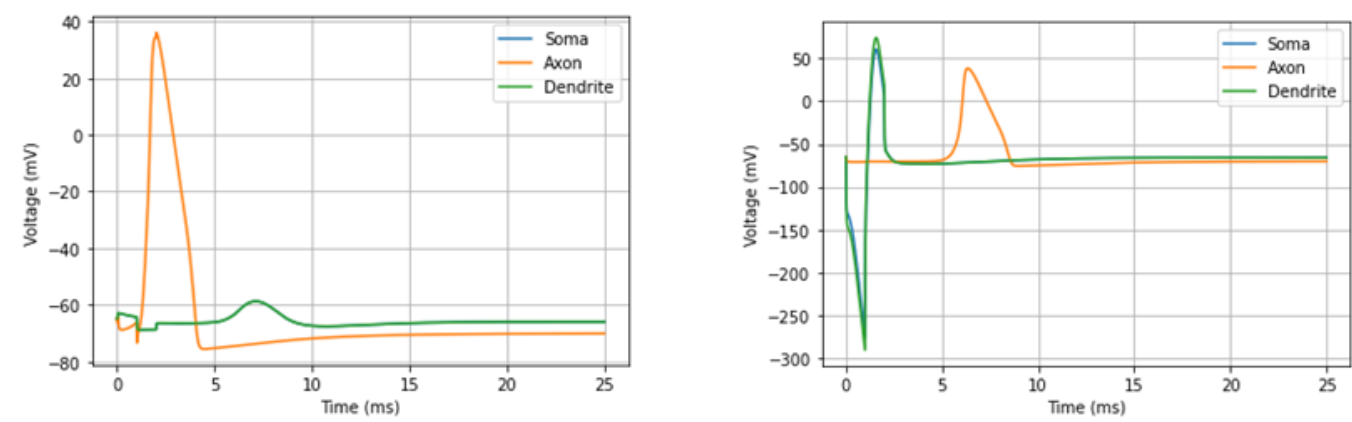

Figure 5. Membrane voltages of the compartments when the electrode is placed to (left) the top and (right) bottom part of the model

Membrane voltages show that when the electrode is placed near the top of the neuron, as a nearest neural compartment, axonal elements generates an action potential as shown in Fig. 5left. As we also see from the Fig. 4, extracellular voltage dramatically decreases as it moves away the electrode, so the extracellular voltage doesn't seem enough to trigger an action potential for soma and dendrite. In the other case, it is seen that membrane voltages of soma and dendrite indicates a firing earlier than axonal compartments. The membrane properties of soma and dendrite make it very difficult to fire because of high membrane capacitance, high membrane resistivity and low Na conductance density. It fires because the electrode is spatially quite close situated to soma and dendrite. The time difference between two action potentials in the Fig. 5-right arises from that electrode is closer to soma and dendrite than axon.

\section{Conclusions and Recommendations}

Computational modeling of pyramidal cells that form the majority of excitatory neuron type in the cerebral cortex, more than $70 \%$ of all neurons in mammalian cortex, shows how accurately a multi-compartmental model can predict neural response to an extracellular stimulation. In addition to experimental work, it makes possible to investigate each types of cell's response to various cases either from electrode design perspective or from stimulation settings. Using neuron models with realistic morphology makes the model well-suited and realistic for further comparison and integration with experimental findings.

\section{Acknowledge}

This work is supported by the Fulbright Scholar Program with ID of PS00304539.

\section{References}

1. Viventi, J., Kim, D. H., Vigeland, L., Frechette, E. S., Blanco, J. A., Kim, Y. S., ... \& Litt, B. (2011). Flexible, foldable, actively multiplexed, high-density electrode array for mapping brain activity in vivo. Nature neuroscience, 14(12), 1599-1605.

2. Rosin, B., Slovik, M., Mitelman, R., Rivlin-Etzion, M., Haber, S. N., Israel, Z., ... \& Bergman, H. (2011). Closedloop deep brain stimulation is superior in ameliorating parkinsonism. Neuron, 72(2), 370-384.

3. Wray, C. D., Blakely, T. M., Poliachik, S. L., Poliakov, A., McDaniel, S. S., Novotny, E. J., ... \& Ojemann, J. G. (2012). Multimodality localization of the sensorimotor cortex in pediatric patients undergoing epilepsy surgery. Journal of Neurosurgery: Pediatrics, 10(1), 1-6.

4. Schroeder, K. E., \& Chestek, C. A. (2016). Intracortical brain-machine interfaces advance sensorimotor neuroscience. Frontiers in neuroscience, 10, 291.

5. Moxon, K. A., \& Foffani, G. (2015). Brain-machine interfaces beyond neuroprosthetics. Neuron, 86(1), 55-67.

6. Moffitt, M. A., \& McIntyre, C. C. (2005). Model-based analysis of cortical recording with silicon microelectrodes. Clinical neurophysiology, 116(9), 22402250.

7. Jorfi, M., Skousen, J. L., Weder, C., \& Capadona, J. R. (2014). Progress towards biocompatible intracortical microelectrodes for neural interfacing applications. Journal of neural engineering, 12(1), 011001.

8. Luan, L., Wei, X., Zhao, Z., Siegel, J. J., Potnis, O., Tuppen, C. A., ... \& Xie, C. (2017). Ultraflexible nanoelectronic probes form reliable, glial scar-free neural integration. Science advances, 3(2), e1601966.

9. Patel, P. R., Zhang, H., Robbins, M. T., Nofar, J. B., Marshall, S. P., Kobylarek, M. J., ... \& Chestek, C. A. (2016). Chronic in vivo stability assessment of carbon fiber microelectrode arrays. Journal of neural engineering, 13(6), 066002.

10. Biran, R., Martin, D. C., \& Tresco, P. A. (2005). Neuronal cell loss accompanies the brain tissue response to chronically implanted silicon microelectrode arrays. Experimental neurology, 195(1), 115-126.

11. Holt, G. R., \& Koch, C. (1999). Electrical interactions via the extracellular potential near cell bodies. Journal of computational neuroscience, 6(2), 169-184.

12. Degenhart, A. D., Eles, J., Dum, R., Mischel, J. L., Smalianchuk, I., Endler, B., ... \& Cui, X. T. (2016). Histological evaluation of a chronically-implanted electrocorticographic electrode grid in a non-human primate. Journal of neural engineering, 13(4), 046019.

13. Nguyen, J. K., Park, D. J., Skousen, J. L., Hess-Dunning, A. E., Tyler, D. J., Rowan, S. J., ... \& Capadona, J. R. (2014). Mechanically-compliant intracortical implants reduce the neuroinflammatory response. Journal of neural engineering, 11(5), 056014.

14. Khodagholy, D., Gelinas, J. N., Thesen, T., Doyle, W., Devinsky, O., Malliaras, G. G., \& Buzsáki, G. (2015). NeuroGrid: recording action potentials from the surface of the brain. Nature neuroscience, 18(2), 310-315.

15. Badia, J., Boretius, T., Andreu, D., Azevedo-Coste, C., Stieglitz, T., \& Navarro, X. (2011). Comparative analysis of transverse intrafascicular multichannel, longitudinal intrafascicular and multipolar cuff electrodes for the selective stimulation of nerve fascicles. Journal of neural engineering, 8(3), 036023. 
16. Bucksot, Jesse E., et al. "Flat electrode contacts for vagus nerve stimulation." PloS one 14.11 (2019): e0215191.

17. Grill, W. M., S. E. Cooper, and E. B. Montgomery. "Effect of stimulus waveform on tremor suppression and paresthesias evoked by thalamic deep brain stimulation." Society for Neuroscience Abstracts. Vol. 29. 2003.

18. Hodgkin, A. L., \& Huxley, A. F. (1952). A quantitative description of membrane current and its application to conduction and excitation in nerve. The Journal of physiology, 117(4), 500-544.

19. Haberly, L. B. (1990). Comparative aspects of olfactory cortex. In Cerebral cortex (pp. 137-166). Springer, Boston, MA.

20. Mainen, Z. F., Joerges, J., Huguenard, J. R., \& Sejnowski, T. J. (1995). A model of spike initiation in neocortical pyramidal neurons. Neuron, 15(6), 1427-1439.

21. Dayan, P., \& Abbott, L. F. (2001). Theoretical neuroscience: computational and mathematical modeling of neural systems. Computational Neuroscience Series. 